\title{
Effectiveness of Herbal Extract (Piper retrofractum, Curcuma aeruginosa, and Curcuma zanthorrhiza) as Immunomodulator in Non-Specific Immunity System of Tiger Grouper (Epinephelus fuscoguttatus) against Infection from Vibrio alginolyticus and Vibrio parahaemolyticus.
}

\author{
Wilis Ari Setyati ${ }^{1 *}$, Subagiyo ${ }^{1}$, Rini Pramesti ${ }^{1}$, Delianis Pringgenies ${ }^{1}$ \\ ${ }^{1}$ Department of Marine Science, Diponegoro University, Semarang, Indonesia Faculty of Fisheries and Marine Sciences, Diponegoro University, Semarang, Indonesia \\ *Corresponding author: wilisarisetyati@yahoo.co.id
}

\begin{abstract}
The success of aquaculture is one of the supporting factors in food sustainability, one of such is the aquaculture of tiger grouper (Epinephelus fuscoguttatus). The main issue of tiger grouper (Epinephelus fuscoguttatus) aquaculture is disease infestation caused by viruses, microbes, and fungi. One of the technologies to control such infestation is the immunostimulant of non-specific immunity. Traditional herbs such as Piper retrofractum, Curcuma aeruginosa, and Curcuma zanthorrhiza have been proven to enhance the immunity system. This study aims to determine the optimal dosage of herb extract (Piper retrofractum, Curcuma aeruginosa, and Curcuma zanthorrhiza) to strengthen non-specific immunity of tiger grouper (Epinephelus fuscoguttatus), to record data on total leukocyte count and phagocytosis activity in the subject against pathogenic infection from Vibrio alginolyticus and Vibrio parahaemolyticus, and on the side effects of the application of the herbal extracts on meat quality (organoleptic) of tiger grouper (Epinephelus fuscoguttatus). The study was carried out by experimental method using random design with 3 repetitions. The experiment was performed in plastic tanks using flow through system with siphon construction. Steps performed include: Herb sample collection, herb samples extraction, herb extract supplementation into artificial food, dose optimization of herb extract application, challenge test, and side effect test. The result shows that treatment with $1 \%$ Piper retrofractum, $0.5 \%$ Curcuma aeruginosa, and 1\% Curcuma zanthorrhiza herb extract increased total leukocyte count and phagocytosis activity in tiger grouper (Epinephelus fuscoguttatus). Organoleptic test of all three treatments indicated similar results, with solid texture and bland flavor. Challenge test against pathogenic infection from $V$. alginolyticus and $V$. parahaemolyticus found that the treatment reduced the mortality rate to $0 \%$. Based on the results of this study, Piper retrofractum, Curcuma aeruginosa, and Curcuma zanthorrhiza were proven to be viable immunomodulator on non-specific immunity system in tiger grouper (Epinephelus fuscoguttatus) fish against infection from Vibrio alginolyticus and Vibrio parahaemolyticus.
\end{abstract}

Keywords

Immunomodulators, Nonspecific Immunity, tiger grouper, Vibrio alginolyticus, Vibrio parahaemolyticus.

Received: 11 September 2019, Accepted: 14 October 2019

https://doi.org/10.26554/sti.2019.4.4.94-100

\section{INTRODUCTION}

The success of aquaculture is one of the supporting factors in food sustainability. This is evident by the increase in national and global demand for fisheries products as a source of nutrition (Paruntu, 2015). tiger grouper fish (Epinephelus fuscoguttatus) is one of the highly profitable aquaculture species, with high demand in Southeast Asian market (Pierre et al., 2008; Yamamoto, 2006; S, 1989). The main challenge of tiger grouper fish aquaculture business is disease from infestation of virus, microbes and fungi (Garcia-Ortega et al., 2016). Lack of knowledge on crop health maintenance causes high mortality and low yield.
Fish, like many animals in general, possess immunity systems against pathogenic invasion which consist of non-specific and induced (specific/adaptive) immunities (Baojiang, 1994). Nonspecific immunity system is also known as innate immunity system. The components of non-specific immunity system are natural cytotoxic cells, leukocytes, granulocytes (neutrophils, granulated eosinophilic cells) and monocyte cells or macrophage derivatives. Its humoral components, among other complementaries, are transferrins, lectins, interferons, prophenoloxidase Creactive protein, agglutinative factor and a number of immunityrelated enzymes (Izzati and Sumarno, 2014).

One of the most potential technologies to be developed in dis- 
ease control is the use of stimulants for non-specific immunity system (Chakraborty and Hancz, 2011). The presently available immunostimulant agents for non-specific immunity system are developed from cell walls of microbes and yeast. These immunostimulants do not possess additional benefits, in that it does not acts as antimicrobial, antifungi, antivirus, etc (Dwyana and Haedar, 2016). Applications of herbs such as Piper retrofractum, Curcuma aeruginosa, and Curcuma zanthorrhiza, which has been traditionally used by Javanese community to increase body immunity and which acts as antimicrobial, antifungal, antiviral, and high-level antioxidants may yield better immunostimulants (Middleton et al., 2000). Therefore, exploration and testing of various sources for immunostimulants from traditional herbal medicine with additional beneficial effects in an effort to discover better, simpler, and more affordable immunostimulants should be carried out.

Piper retrofractum (Piper retrofractum) is an Indonesian native medicinal herbs. Spicy substances in Piper retrofractum includes piperine, chavicine, palmitic acid, tetrahydropiperic acid, 1-undecylenoyl-3, 4-methylenedioxybenzene, piperidine, essential oil, $\mathrm{N}$-isobutyl-deca-trans-4-dienamide, and sesamin. Piperine is a known antipyretic, analgesic, anti-inflammation, and suppressant which works in the central nervous system (Haryudin and Rostiana, 2011). Curcuma aeruginosa (Curcuma xanthorrhiza Roxb.) is a plant well-known among the Javanese community for treatment of various illnesses (Kuntorini, 2011). The essential oil component of Curcuma aeruginosa (Curcuma xanthorrhiza Roxb.) rhizome is xanthorrizol. Xanthorrizol has antimicrobial, antiseptic, and antibiotic properties (Nita, 2014). The Curcuma zanthorrhiza (Curcuma aeruginosa Roxb.) is one of the medicinal plants in Indonesia. It is known to contain saponin, flavonoid, amylum, fat, bitter compound, blue pigment, tannin, and polyphenol as well as 0.3-2 \% essential oil (Sari and Cikta, 2016). Gofar et al. (2018) explain that several compound from plant such as alkaloid, aromatic compound, peptide and depipeptide cyclic has an ability as an antimicrobia. Flavonoid is also a polyphenol compound. This compound is derived from 2phenylchromen or 2-phenylbenzopyrone. This compound help in treatment of inflammation due to its antimicrobial, antiviral and antihistaminic properties (Willaman, 1955), and its action as a reductor, an anti-hypertension, and an estrogen production stimulant (Robinson, 1995), as well as an antifungal and an insecticide agent Geissman (1962).

This study aims to (1) Determine the optimal dose of herb extract (Piper retrofractum, Curcuma aeruginosa, and Curcuma zanthorrhiza) to enhance the non-specific immunity system of tiger grouper fish (Epinephelus fuscoguttatus), (2) Obtain data on total leukocyte count and level of phagocytosis activity in tiger grouper fish (Epinephelus fuscoguttatus) due to the administration of herb extract (Piper retrofractum, Curcuma aeruginosa, and Curcuma zanthorrhiza), (3) Obtain the data of the potency of herb extract (Piper retrofractum, Curcuma aeruginosa, and Curcuma zanthorrhiza) in protecting tiger grouper fish (Epinephelus fuscoguttatus) from the infection caused by Vibrio alginolyticus and Vibrio parahaemolyticus, (4) Obtain data on the side effect of the introduction of the herb extract (Piper retrofractum, Curcuma aeruginosa, and Curcuma zanthorrhiza) as immunomodulator agent on the organoleptic quality of tiger grouper (Epinephelus fuscoguttatus) fish meat.

\section{EXPERIMENTAL SECTION}

\subsection{Materials and Methods}

Herbal extract tested on the tiger grouper (Epinephelus fuscoguttatus) fish consisted of (1) Piper retrofractum juice extract, (2) Curcuma aeruginosa juice extract, and (3) Curcuma zanthorrhiza juice extract. The study was performed using experimental method with random group design and 3 repetitions. The experiment was conducted inside plastic tanks with flow through system with siphon construction.

\subsection{Sample Collection}

Samples were collected based on field survey and survey of traditional Javanese herbal medicine (Jamu) producers. The samples were sorted in accordance with applicable quality standards in the Jamu industry. All samples were cleaned from grimes and dirt. Preparation of samples herb was done according to Suharmiati and Handayani (2006).

\subsection{Extraction of The Herbs}

Herb samples were extracted using maceration techniques according to Setyati (2007). The extraction process employed hot water extraction technique. Herb samples were air-dried and were removed from non-essential compounds, such as wax film, by maceration using organic solvent. The remains of maceration were put into a rotavapor for hot water extraction process.

\subsection{Herb Extracts Supplementation into Fish Feed}

Supplementation of herbal extracts or powdered simplicia for the treatment of tiger grouper (Epinephelus fuscoguttatus) test subjects was carried out by mixing in commercial grouper feed based on the research by Setyati (2007). Pellets were ground and then sieved. The powdered simplicia was added homogenically at $10 \mathrm{~g} / \mathrm{kg}$ of dose. Pellets making process then took place.

\subsection{Optimization of Dose in The Application of Herb Ex- tracts}

Dose optimization was carried out by varying the dose of the applications, namely at $0.5 \%, 1 \%, 1.5 \%$. The dose range was set to what was used in the research by Setyati (2007). The dose combinations were developed based on physiological effects of each extract, which was expected to induce stronger immunomodulation.

The tiger grouper (Epinephelus fuscoguttatus) fish in this study were obtained from Office of Brackish Water Aquaculture (BBAP) of Situbondo. Fish in similar size, $10 \mathrm{~cm}$, were selected as subjects. Before conducting the experiment, the subjects were put into acclimation period, using a modified method employed in a study by Rodriguez et al. (2003). The acclimation period lasted for 15 days. The subjects were fed according to the protocol mentioned in Couso et al. (2003). Administration of 
Table 1. Total Leukocyte Count of tiger grouper fish (Epinephelus fuscoguttatus) with Dose Treatment of Piper retrofractum Juice Extract, Curcuma zanthorrhiza Juice Extract, and Curcuma aeruginosa Juice Extract.

\begin{tabular}{ccccc}
\hline \multirow{2}{*}{ Dose Treatment } & & \multicolumn{3}{c}{ Total Leukocyte Count (Cells/Lt) } \\
& & $\mathrm{T} 1$ & $\mathrm{~T} 2$ & T3 \\
\hline Piper retrofractum Juice Extract & $0.50 \%$ & $7.62 \pm 1.044 \mathrm{a}$ & $11.786 \pm 1.746 \mathrm{a}$ & $19.533 \pm 1.286 \mathrm{~b}$ \\
& $1 \%$ & $7.04 \pm 0.835 \mathrm{a}$ & $11.373 \pm 0.211 \mathrm{a}$ & $12.673 \pm 2.315 \mathrm{a}$ \\
& $1.50 \%$ & $6.6 \pm 1.335 \mathrm{a}$ & $10.266 \pm 1.183 \mathrm{a}$ & $12.991 \pm 1.325 \mathrm{a}$ \\
Curcuma zanthorrhiza Juice Extract & $0.50 \%$ & $1.158 \pm 0.097 \mathrm{a}$ & $19.06 \pm 7.787 \mathrm{a}$ & $26.186 \pm 8.166 \mathrm{a}$ \\
& $1 \%$ & $0.828 \pm 0.155 \mathrm{a}$ & $9.143 \pm 2.831 \mathrm{a}$ & $33.313 \pm 6.781 \mathrm{a}$ \\
& $1.50 \%$ & $1.025 \pm 0.372 \mathrm{a}$ & $17.986 \pm 1.848 \mathrm{a}$ & $30.406 \pm 5.879 \mathrm{a}$ \\
Curcuma aeruginosa Juice Extract & $0.50 \%$ & $0.686 \pm 0.267 \mathrm{a}$ & $1.388 \pm 0.059 \mathrm{a}$ & $14.346 \pm 1.609 \mathrm{a}$ \\
& $1 \%$ & $0.726 \pm 0.213 \mathrm{a}$ & $10.056 \pm 1.888 \mathrm{~b}$ & $14.986 \pm 2.641 \mathrm{a}$ \\
& $1.50 \%$ & $5.532 \pm 0.632 \mathrm{a}$ & $1.955 \pm 1.519 \mathrm{a}$ & $11.766 \pm 1.043 \mathrm{a}$ \\
\hline
\end{tabular}

herb extracts were performed through feeding, at various dose (gram $/ \mathrm{kg}$ ) of feeding. A control group was set up which receives feeding with no introduction of herb extract supplement.

Immunomodulation activity test of the herb extracts for tiger grouper (Epinephelus fuscoguttatus) fish was achieved by performing the following hematology tests:

- Total leukocyte count

The total leukocyte count was performed using Neubauer Counting Chamber method as presented in Isnansetyo (2007). The total leukocyte count uses the following formula:

$$
T H C=\frac{\text { TotalCellCounted }}{\text { VolumeCounted }} \times \text { Dilution }\left(x 10^{6}\right)
$$

\section{- Phagocytosis activity test}

The procedure to determine phagocytosis activity follows that of Isnansetyo (2007). The Phagocytosis activity is determined by the following formula:

$$
A F \%=\frac{\text { SPhagocyteActive }}{\text { SPhagocyteObserved }} \times 100 \%
$$

\subsection{Challenge Test}

Challenge tests were carried out to determine whether herb extracts had significant activity against diseases caused by Vibrio alginolyticus and Vibrio parahaemolyticus infections. The challenge test in this study was done by experiment. The test parameters were: (1) percentage of infection prevalence (morphological and anatomical abilities), (2) survival rate

\subsection{Side Effect Test}

The side effect test was performed to determine how the introduction of herb extract affects meat quality by organoleptic assessment. The meat quality was tested by a number of panelists. The organoleptic properties tested include color, texture, flavor, and taste.

\section{RESULTS AND DISCUSSION}

Total Leukocyte Count data presented in Table 1 shows that treatment with Piper retrofractum juice extract at $0.5 \%, 1 \%$, and
$1.5 \%$ dose produced different results during the 12-day treatment period. However, introduction of Curcuma zanthorrhiza extract at all doses did not show significantly distinct results. The addition of Curcuma aeruginosa extract showed significant difference in results between the $1.5 \%$ dose and the other two. This treatment group also showed a gain in total leukocyte count on day 4 and day 8 , between $1 \%$ dose group and $1.5 \%$ dose group.

The highest total leukocyte count in tiger grouper fish (Epinephelus fuscoguttatus) was found in the Curcuma zanthorrhiza juice extract treatment group. This shows that Curcuma zanthorrhiza has the highest contents of immunity enhancing compounds compared with Piper retrofractum and Curcuma aeruginosa. Based on the analysis of the data, lymphocyte was found to be the dominating sub-type of leukocyte. Lymphocyte provides immunity compounds for the body and is found in large amount, even when the infection is receding (Herlina, 2017). The increase in leukocyte count (leukocytosis) is related to the mechanism of the subjects' body immunity in reucing pathogenic attacks. The amount of each sub-type of leukocyte (neutrophils, monocyte, lymphocyte) is limited in blood circulation, and that number increases in the event of pathogenic infection. The cells produced and massively proliferated at the onset of an infection are neutrophils (Kumar, 2016). The percentage of lymphocytes reported are $0 \%-80 \%$ (Johny et al., 2003), whereas Johny et al. (2003) reported in napoleon, $75.0 \%$ in Barramundi, $72.4 \%$ in Milkfish, $71.2 \%$ in grouper, $70.4 \%$ in humpback grouper, $68.3 \%$ in tiger grouper.

Table 2 shows that the different doses of Java long pepper extract have an effect on phagocytic activity, between $0.5 \%$ and $1 \%$ and $1.5 \%$, which occurs in the treatment application on day 4 and day 8 . The data also showed that the most potent dose is at $1 \%$. The treatment of Curcuma zanthorrhiza extract did not produce a difference in value caused by differences in the dosage of the application. Based on the results, the most potent dose for this treatment is at $0.5 \%$. Whereas in the application of Curcuma aeruginosa, the phagocytosis activity was seen between application dosages of $0.5 \%$ and $1.5 \%$, which were seen on day 8 . Based on the results, the most potent dose for this treatment is 
Table 2. Phagocytosis Activity in tiger grouper fish (Epinephelus fuscoguttatus) at Dose Treatment of Piper retrofractum Juice Extract, Curcuma zanthorrhiza Juice Extract, and Curcuma aeruginosa Juice Extract.

\begin{tabular}{ccccc}
\hline \multirow{2}{*}{ Dose Treatment } & & \multicolumn{3}{c}{ Phagocytosis Activity $(\%)$} \\
& & T1 & T2 & T3 \\
\hline Piper retrofractum Juice Extract & $0.50 \%$ & $0.364 \pm 0.134 \mathrm{~b}$ & $0.390 \pm 0.033 \mathrm{a}$ & $0.406 \pm 0.030 \mathrm{a}$ \\
& $1 \%$ & $0.753 \pm 0.058 \mathrm{a}$ & $0.506 \pm 0.030 \mathrm{a}$ & $0.502 \pm 0.039 \mathrm{a}$ \\
& $1.50 \%$ & $0.816 \pm 0.050 \mathrm{a}$ & $0.855 \pm 0.076 \mathrm{~b}$ & $0.380 \pm 0.114 \mathrm{a}$ \\
Curcuma zanthorrhiza Juice Extract & $0.50 \%$ & $0.295 \pm 0.079 \mathrm{a}$ & $0.382 \pm 0.091 \mathrm{a}$ & $0.910 \pm 0.018 \mathrm{~b}$ \\
& $1 \%$ & $0.319 \pm 0.105 \mathrm{a}$ & $0.441 \pm 0.049 \mathrm{a}$ & $0.878 \pm 0.005 \mathrm{a}$ \\
& $1.50 \%$ & $0.341 \pm 0.084 \mathrm{a}$ & $0.539 \pm 0.143 \mathrm{a}$ & $0.871 \pm 0.008 \mathrm{a}$ \\
Curcuma aeruginosa Juice Extract & $0.50 \%$ & $0.855 \pm 0.029 \mathrm{a}$ & $0.471 \pm 0.027 \mathrm{ab}$ & $0.875 \pm 0.018 \mathrm{a}$ \\
& $1 \%$ & $0.839 \pm 0.032 \mathrm{a}$ & $0.418 \pm 0.034 \mathrm{a}$ & $0.856 \pm 0.006 \mathrm{a}$ \\
& $1.50 \%$ & $0.858 \pm 0.026 \mathrm{a}$ & $0.365 \pm 0.018 \mathrm{ac}$ & $0.889 \pm 0.018 \mathrm{a}$ \\
\hline
\end{tabular}

Table 3. Phagocytosis Index in tiger grouper fish (Epinephelus fuscoguttatus) at Dose Treatment of Piper retrofractum Juice Extract, Curcuma zanthorrhiza Juice Extract, and Curcuma aeruginosa Juice Extract.

\begin{tabular}{ccccc}
\hline Dose Treatment & & \multicolumn{3}{c}{ IF Observation } \\
& & $\mathrm{T} 1$ & T2 & T3 \\
\hline Piper retrofractum Juice Extract & $0.50 \%$ & $0.687 \pm 0.308 \mathrm{a}$ & $0.743 \pm 0.057 \mathrm{ab}$ & $0.720 \pm 0.160 \mathrm{a}$ \\
& $1 \%$ & $0.894 \pm 0.066 \mathrm{a}$ & $0.865 \pm 0.031 \mathrm{a}$ & $0.991 \pm 0.040 \mathrm{a}$ \\
Curcuma zanthorrhiza Juice Extract & $1.50 \%$ & $1.068 \pm 0.145 \mathrm{a}$ & $0.971 \pm 0.074 \mathrm{ac}$ & $0.796 \pm 0.115 \mathrm{a}$ \\
& $0.50 \%$ & $0.516 \pm 0.125 \mathrm{a}$ & $0.819 \pm 0.296 \mathrm{a}$ & $1.051 \pm 0.038 \mathrm{a}$ \\
& $1 \%$ & $0.464 \pm 0.175 \mathrm{a}$ & $0.764 \pm 0.093 \mathrm{a}$ & $1.002 \pm 0.037 \mathrm{a}$ \\
Curcuma aeruginosa Juice Extract & $0.50 \%$ & $1.019 \pm 0.051 \mathrm{a}$ & $0.900 \pm 0.160 \mathrm{ab}$ & $0.996 \pm 0.046 \mathrm{a}$ \\
& $1 \%$ & $0.979 \pm 0.133 \mathrm{a}$ & $0.667 \pm 0.082 \mathrm{a}$ & $1.020 \pm 0.046 \mathrm{a}$ \\
& $1.50 \%$ & $0.620 \pm 0.026 \mathrm{a}$ & $0.620 \pm 0.026 \mathrm{ac}$ & $1.026 \pm 0.062 \mathrm{a}$ \\
\hline
\end{tabular}

at $1 \%$.

The highest phagocytosis activity in tiger grouper fish (Epinephelus fuscoguttatus) was found in the Curcuma zanthorrhiza juice extract treatment group. The resulting values indicates an increase in immunity system response against pathogenic infection in the form of increased phagocytosis, where monocyte cells are one of the phagocytic cells which is used in non-specific immunity system. According to Wulandari et al. (2018)), fish monocyte cells are round (oval), with the nucleus located in the middle of the cell, and nongranular cytoplasm. Furthermore, Kumar et al. (2018) elaborated that monocytic cells are more capable in antigen phagocytosis compared to neutrophils. Xiong and Pamer (2015), explains that the workings of monocyte cells in killing or lysing bacterial cells, wherein the process is present in the chemotaxic phase, attachment, capture, ingestion and killing of microbes. Abas A (2005) explained that monocyte cells can multiply rapidly in the inflammatory region, which then devours the infectious agent when an attack occurs. Cholik et al. (2005), states that in the inflammatory process when tissue damage occurs by infection or antigen-antibody reaction will increase monocyte production to twice as much. Circulation of monocytes in the blood becomes shorter, maturation of monocytes into macrophages is faster, and the macrophage immediately heads to the damaged tissue.

The increase in total leukocyte count and percentage of leukocyte blood subtypes can be referenced from the percentage of phagocytic indices (Djurdjevic et al., 2001). The results of the average percentage of phagocytic index of tiger grouper with herbal extract showed phagocytic index values that were not significantly different for each treatment, with an average percentage of phagocytic indexes between $0.133-1.068$. The average percentage of phagocytic index of tiger grouper in each dose treatment showed that the phagocytic index value between $0.5 \%$, $1 \%$ and $1.5 \%$ was not significantly different, but the $1.5 \%$ dose showed the highest average percentage of phagocytic index. This indicates an increase in immunity, because the high phagocytic index value in the dose treatment reflects that the phagocytosis process that occurs quickly contributes to the mechanism of presenting antigen (antigen presenting cells) to stimulate lymphocyte cell responses (Qomariyah et al., 2017).

Challenge tests were performed to determine the ability of herbal extracts to increase fish resistance to microbial infections. Challenge test results on microbial infections (Vibrio bacteria) are presented in Table 4 . Table 4 showed that all herb extract has 
Table 4. Challenge Test against V. alginolyticus and V. parahaemolyticus tiger grouper fish (Epinephelus fuscoguttatus)

\begin{tabular}{lcccccc}
\hline & \multirow{2}{*}{ Treatment } & \multicolumn{3}{c}{ Mortality (\%) } & Clinical \\
& & $12 \mathrm{~h}$ & $24 \mathrm{~h}$ & $36 \mathrm{~h}$ & $48 \mathrm{~h}$ & Symptoms \\
\hline V. alginolyticus & Control & 20 & 40 & 80 & 80 & Mouth, pectoral fins, and tails are red. \\
& Piper retrofractum Juice Extract & 0 & 0 & 0 & 0 & - \\
& Curcuma zanthorrhiza Juice Extract & 0 & 0 & 0 & 0 & - \\
V. paraha- & Curcuma aeruginosa Juice Extract & 0 & 0 & 0 & 0 & - \\
emolyticus & Control & 0 & 0 & 0 & 20 & Mouth, pectoral fins, and tails are red. \\
& Piper retrofractum Juice Extract & 0 & 0 & 0 & 0 & - \\
& Curcuma zanthorrhiza Juice Extract & 0 & 0 & 0 & 0 & - \\
\hline
\end{tabular}

the potency to enhance immunity of tiger grouper fish against infections caused by $V$. alginolyticus dan V. parahaemolyticus pathogenic microbes, with a mortality rate of 0 . The results indicate that the addition of Piper retrofractum juice extract, Curcuma zanthorrhiza juice extract, and Curcuma aeruginosa juice extract is effective in increasing fish resistance against microbial infection.

According to Rahayu (2016), 5 types of active substances are found in Curcuma aeruginosa, with the highest composition being curcumin (38.60\%), followed by turmerone (27.62\%) and xanthorrizol (19.27\%). Curcuma aeruginosa contains xanthorrizol, an active substance which inhibits the infestation of pathogenic microbes. Rukayadi and Hwang (2007) state that this compound is a very potential antifungal, helping to cure candidiasis in humans caused by 4 types of candida species, namely C. albicans, C. glabrata, C. guillermondii, and C. parapsilosis. Xanthorrhizol besides possessing antifungal activity, also have antimicrobial properties. Microbes sensitive to xanthorrizol are Streptococcus sp, Staphylococcus aureus and E. coli.

Based on organoleptic tests (Table. 5), the treatment which caused a decrease in the quality of meat (leaving residual aroma and flavor of herbs, causing meat to taste bitter and soft-textured) was $1 \%$ Curcuma aeruginosa extract, $1 \%$ Curcuma zanthorrhiza extract, $1 \%$ Piper retrofractum extract. The application of a combination of herbal extracts causes the texture of fish meat to be soft. The parameters of the organoleptic test results are influenced by the innate characteristics of herbal extracts, where curcumin is one of the ingredients found in Curcuma aeruginosa rhizome, Curcuma zanthorrhiza rhizome and in Piper retrofractum. This curcumin content is attributed to the bitter taste of Curcuma aeruginosa (Supandi and Amalia, 2016).

\section{CONCLUSIONS}

Based on the findings of the study, it can be concluded that, The optimum dose of herbal herbal extracts against the non-specific immune system of tiger grouper (Epinephelus fuscoguttatus), namely in the water extract of Piper retrofractum concentration of $0.5 \%$ with total leukocyte count ie $19,533 \pm 1,286 \mathrm{~b}$ and phagocytic activity of $0.406 \pm 0.030$ a on extract water Curcuma aeruginosa concentration of $0.5 \%$ with total leukocyte count of
$36,186 \pm 8,166 \mathrm{a}$ and phagocytic activity of $1,051 \pm 0.038 \mathrm{a}$ and in Curcuma zanthorrhiza the concentration of $0.5 \%$ with total leukocyte counts of $14,986 \pm 2,641 \mathrm{a}$ and phagocytic activity of $0.996 \pm 0.046 \mathrm{a}$. Challenge test results of tiger grouper show that giving all types of treatment of water herbal extracts Piper retrofractum, Curcuma aeruginosa and Curcuma zanthorrhiza have the protective ability of tiger grouper against pathogenic bacterial infections $V$. alginolyticus and $V$. parahaemolyticus with a level of moratlitas 0 which means water herbal extracts Piper retrofractum, Curcuma aeruginosa and Curcuma zanthorrhiza are very effective for boosting the immune system against bacteria. Changes in the quality of tiger grouper fish (Epinephelus fuscoguttatus) occur in the addition of $0.5 \%$ Curcuma aeruginosa extract which causes the texture of the meat to be soft, $1 \%$ Curcuma aeruginosa extract which causes a bitter taste in $1 \%$ Curcuma zanthorrhiza extract and meat soft.

\section{REFERENCES}

Abas A, D. J., Lichtman AH (2005). Cellular and Philadelphia. Elsevier Saunders

Baojiang, G. (1994). Study on effect and mechanism of polysaccharides of Spirulina platensis on body immune functions improvement. Book of Abstracts. Second Asia Pacific Conference on Algal Biotechnology

Chakraborty, S. and C. Hancz (2011). Application of phytochemicals as immunostimulant, antipathogenic and antistress agents in finfish culture. Reviews in Aquaculture, 3

Cholik, F., A. Jagatraya, R. Poernomo, and A. Jauzi (2005). Akuakultur Masyarakat Perikanan Nusantara (MPN) dan Taman Kuarium Air Tawar, Jakarta

Couso, N., R. Castro, B. Magarinos, A. Obach, and J. Lamas (2003). Effect of oral administration of glucans on the resistance of gilthead seabream to Pasteurellosis. Aquaculture, 219; 99-109

Djurdjevic, P., N. Arsenijevic, D. Baskic, A. Djukic, S. Popovic, and G. Samardzic (2001). Systemic response of peripheral blood leukocytes and their phagocytic activity during acute myocardial infarction. Experimental and clinical cardiology, 6; $159-66$

Dwyana, Z. and H. N. Haedar (2016). Potensi Beberapa Isolat Probiotik Sebagai Antibakteri Terhadap Pertumbuhan Vib- 
Table 5. Organoleptic Test on Fish Meat with Dose Treatment of Piper retrofractum Juice Extract, Curcuma zanthorrhiza Juice Extract, and Curcuma aeruginosa Juice Extract.

\begin{tabular}{cccccc}
\hline \multirow{2}{*}{ Treatment } & & \multicolumn{3}{c}{ Organoleptic Parameters } \\
& & Flavor & Texture & Meat Taste & Herbal Taste \\
\hline Piper retrofractum Extract & $0.50 \%$ & None & Solid & Bland & None \\
& $1 \%$ & None & Solid & Bland & None \\
& $1.50 \%$ & None & Firm & Bland & None \\
Curcuma zanthorrhiza Extract & $0.50 \%$ & None & Soft & Bland & None \\
& $1 \%$ & None & Firm & Bitter & None \\
& $1.50 \%$ & None & Firm & Sweet & None \\
Curcuma aeruginosa Extract & $0.50 \%$ & None & Firm & Bland & None \\
& $1 \%$ & Mild & Soft & Bland & None \\
& $1.50 \%$ & None & Firm & Sweet & None \\
\hline
\end{tabular}

rio spp. In Prosiding Seminar Nasional From Basic Science to Comprehensive Education. pages 127-134

Garcia-Ortega, A., K. R. Kissinger, and J. T. Trushenski (2016). Evaluation of fish meal and fish oil replacement by soybean protein and algal meal from Schizochytrium limacinum in diets for giant grouper Epinephelus lanceolatus. Aquaculture, 452; $1-8$

Geissman, T. (1962). The Chemistry of Flavonoid Compounds. The Macmillan Company, 100(1); 60-61

Gofar, N., A. Diana, and E. Setianingsih (2018). Potential of Anabaena Azollae Extract as Antimicrobial Agent For Paddy Crop Disease. Science and Technology Indonesia, 3(4); 183

Haryudin, W. and O. Rostiana (2011). Stabilitas Karakter Morfologi 10 Aksesi Cabe Jawa (Piper retrofractum Vahl.) Di Kebun Percobaan Cikampek. Bul. Littro, 21(2); 13-22

Herlina, S. (2017). Efektivitas Ekstrak Daun Mengkudu (Morinda citrifolia)untuk Meningkatkan Respon Imun Non Spesifik dan Kelangsungan Hidup Ikan Mas (Cyprinus carpio). Jurnal Ilmu Hewani Tropika, 6(1); 1-4

Isnansetyo, A. (2007). Petunjuk Praktikum Hematologi Ikan (Evaluasi Pertahanan Non Spesifik Ikan), Pelatihan Hematologi Ikan, Laboratorium Hama dan Penyakit Ikan. Universitas Gajah Mada:Yogyakarta

Izzati, S. A. and S. W. Sumarno (2014). Peran Komplemen, Fagosit (Leukosit) Dan Antibodi Dalam Menurunkan Jumlah Mycobacterium Tuberculosis. Majalah Kesehatan FK UB, 1(2); 74-81

Johny, F., D. Zafran, and K. M. Roza (2003). Hematologi Beberapa Spesies Ikan Laut Budidaya. Jurnal Penelitian Perikanan Indonesia

Kumar, K. P., A. J. Nicholls, and C. H. Y. Wong (2018). Partners in crime: neutrophils and monocytes/macrophages in inflammation and disease. Cell and Tissue Research, 371(3); 551-565

Kumar, M. V. (2016). Morphometric Studies of Blood Cells in Cyprinus carpio Ctepharyngodanidella and Hypophthalmichthysmolitrix Cultured Fish in West Godavari Region of Andhra Pradesh. International 7. of Fisheris and Aquatic Studies, 4(5); 489-493
Kuntorini, M. D. A. N. M., E. M. (2011). Struktur Anatomi Dan Kerapatan Sel Sekresi Serta Aktivitas Antioksidan Ekstrak Etanol Dari Rimpang Temulawak (Curcuma xanthorrhiza Roxb) Asal Kecamatan Pengaron Kabupaten Banjar Kalimantan Selatan. Bioscientiae, 8(1); 28-37

Middleton, E., C. Kandaswami, and T. C. Theoharides (2000). The Effects of Plant Flavonoids on Mammalian Cells:Implications for Inflammation, Heart Disease, and Cancer. Pharmacological Reviews, 52(4); 673-751

Nita, M. A. U. N. A. D., V. I. (2014). Perbedaan Efektifitas Ekstrak Temulawak (Curcuma xanthorrizae Roxb) dengan Berbagai Konsentrasi Terhadap Pertumbuhan Candida albicans Pada Plat Resin Akrilik Kuring Panas - In Vitro. Odonto Dental fournal, 1(1); 20-25

Paruntu, C. P. (2015). Budidaya Ikan Kerapu (Epinephelus Tauvina Forsskal, 1775) Dan Ikan Beronang (Siganus Canaliculatus Park, 1797) Dalam Karamba Jaring Apung Dengan Sistim Polikultur. Furnal Budidaya Perairan, 3(1); 1-10

Pierre, S., S. Gaillard, N. Prévot-D'Alvise, J. Aubert, O. RostaingCapaillon, D. Leung-Tack, and J.-P. Grillasca (2008). Grouper aquaculture: Asian success and Mediterranean trials. Aquatic Conservation: Marine and Freshwater Ecosystems, 18(3); 297308

Qomariyah, N., H. Suprapto, and S. Sudarno (2017). Pemberian Vaksin Formalin Killed Cell (FKC) Vibrio alginolitycus Untuk Meningkatkan Survival Rate (SR), Titer Antibodi Dan Fagositosis Leukosit Pada Kerapu Cantang (Epinephelus sp.) Setelah Uji Tantang Bakteri Vibrio alginolitycus. furnal Ilmiah Perikanan dan Kelautan, 9; 15

Rahayu, I. D. (2016). Kajian Sensitifitas Zat Aktif Jamu-Jamuan sebagai Antibiotik Alami dalam Pakan terhadap Bakteri dalam Feses Ayam Kampung. SENASPRO (Seminar Nasional dan Gelar Produk); 202-208

Robinson, T. (1995). Kandungan Organik Tumbuhan Tinggi. Penerjemah: Padmawinata,K. Penerbit Itb. Bandung

Rodriguez, A., A. Cuesta, J. Ortuno, M. Esteban, and J. Meseguer (2003). Immunostimulant properties of a cell wall-modified whole Saccharomyces cerevisiae strain administered by diet 
to seabream (Sparus aurata L.). Veterinary Immunology and Immunopathology, 96(3-4); 183-192

Rukayadi, Y. and J.-K. Hwang (2007). In Vitro antimycotic activity of xanthorrhizol isolated fromCurcuma xanthorrhiza Roxb. against opportunistic filamentous fungi. Phytotherapy Research, 21(5); 434-438

S, T. (1989). Review of knowledge on grouper aquaculture in South East Asia.

Sari, A. and E. Cikta (2016). EKSTRAKSI FLAVONOID DARI TEMU IRENG (Curcuma aeruginosa Roxb) DAN APLIKASINYA PADA SABUN TRANSPARAN. JURNAL KONVERSI, 5; 17

Setyati, S. S. S., W. A. (2007). Pengaruh Suplementasi Ekstrak Herbal (Jahe, Temulawak dan Kencur) terhadap Jumlah Total Hemosit dan Aktivitas Fagositosis Udang Putih (Litopenaeus vannamei). Aquakultura Indonesia, 8(3); 155-161

Suharmiati, L. and Handayani (2006). Cara Benar Meracik Obat Tradisional. Agromedia Pustaka:Jakarta

Supandi, M. and N. R. Amalia (2016). Pemanfaatan Temulawak, Jahe Merah, Kunyit Putih, Kapulaga, Bunga Lawang, Daun
Salam Sebagai Bahan Tambahan Pembuatan Jamu. Furnal Teknologi Agro-Industri, 3(2); 15-23

Willaman, J. (1955). Some Biological Effects of the Flavonoids. fournal of the American Pharmaceutical Association (Scientific ed.), 44(7); 404-408

Wulandari, S., R. Jumadi, and F. Rahmawati (2018). EFEKTIVITAS SERBUK DAUN TANAMAN KAYU MANIS (Cinnamomum burmanii) TERHADAP DIFERENSIAL LEUKOSIT DAN AKTIVITAS FAGOSITOSIS IKAN NILA (Oreochoromis niloticus) YANG DIINFEKSI Streptococcus agalactiae. Jurnal Perikanan Pantura (JPP), 1; 40

Xiong, H. and E. G. Pamer (2015). Monocytes and infection: Modulator, messenger and effector. Immunobiology, 220(2); $210-214$

Yamamoto, K. (2006). Asia Pacific Marine Finfish Aquaculture Network (APMFAN) and the effort towards sustainable grouper aquaculture in the region. In Paper Presented at the Naca/Fao Regional Workshop the Future of Mariculture: A Regional Approach for Responsible Development of Marine Farming in The Asia-Pacific Region 